\title{
Farmers' Awareness about Impacts of Reusing Wastewater, Risk Perception and Adaptation to Climate Change in Faisalabad District, Pakistan
}

\author{
Muhammad Tayyab Sohail ${ }^{1 *}$, Xuan Lin $^{2 * *}$, Liang Lizhi ${ }^{1 * * *}$, \\ Muhammad Rizwanullah', Muhammad Nasrullah', Yu Xiuyuan', \\ Zaira Manzoor ${ }^{3}$, Randriamihanta Jery Elis ${ }^{4}$
}

${ }^{1}$ School of Public Administration, Xiangtan University, Hunan Xiangtan, 411105 P.R. China ${ }^{2}$ School of Public Administration, China University of Geosciences Wuhan, 430000 P.R. China

${ }^{3}$ School of Economics, Shandong University Jinan, 250000 P.R. China ${ }^{4}$ Department of Law, Central South University, Changsha, 410000 P.R. China

Received: 7 February 2021

Accepted: 15 March 2021

\begin{abstract}
Water scarceness is the most critical problem for numerous arid and semi-arid areas. It leads to the use of wastewater in many countries. This study was aimed to determine the farmer's awareness about reusing wastewater in their risk perception and adaptation to climate change in district Faisalabad, Pakistan. Faisalabad has become an industrial hub and industrial discharge is becoming problematic for local community and environment. Usually, farmers depend on wastewater for agriculture purposes in many aspects. The present study was divided into two phases, in the first phase a questionnairebased study was conducted in urban and peri-urban areas while in the second phase, wastewater quality parameters were determined ( $\mathrm{pH}, \mathrm{SS}$, TDS, BOD, COD, arsenic, cadmium, chromium, copper, lead, nickel and zinc) and compared with Pakistan Environmental Quality Standards. Results indicated that farmers had a strong awareness $(96.8 \%$ ) about fertility value of wastewater for many aspects, but they were unaware (71.6\%) about health hazard of untreated wastewater used for crop irrigation. In the current study correlation of Determining of Climate Change (DCC) with age and farming experience was highly significant with correlation values 0.48 and 0.40 respectively. Adaption Measures (AM) correlation values with age and farming experience were 0.49 and 0.75 respectively. Other variables livelihood Assets (LA) was also correlated with Determining of Climate Change (DCC) and Adaption Measures (AM) and all variables were found significant week to moderate correlation among all selected variables. Farmers $(>70 \%)$ used different techniques to adapt to climate change like irrigation, seeds,
\end{abstract}

\footnotetext{
*e-mail: tayyabsohail@yahoo.com **e-mail: xuanlin19930522@163.com

***e-mail: 188793258@qq.com
} 
fertilizer and crops. Industrial and sewage wastewater quality of Faisalabad showed higher values than PEQs, creating an alarming situation for local people's health and environment. High metal pollution index $(<1000)$ showed the heavy effluent discharge from industries and putting pressure on groundwater resources as well. It is strongly recommended that water should be treated prior to reuse for irrigation. This study will help to ensure proper monitoring, develop and implementation of public policies for integrated and sustainable water management to minimize the health hazards in district Faisalabad.

Keywords: farmer, climate change, wastewater, fertilizer, Pakistan, Faisalabad

\section{Introduction}

Water pollution has become a major environmental problem [1-3] due to two major sources, natural and anthropogenic, which deteriorate the water and soil resources and violate the legal environmental framework $[4,5]$. The world is making development in industrialization and it leads toward more demand for fresh water [6]. In many countries, where the freshwater resources are scarce, farmers tend to use wastewater as an alternative (as an unplanned activity) to conserve water nutrients for agricultural improvement without using chemical fertilizers. This water contains organic and inorganic pollutants from natural and anthropogenic activities which can have negative effect on human health, freshwater resources, environment and agricultural productivity. Besides these adverse effect's farmers are willing to use this wastewater [7-10]. It is estimated that about 200 million farmers irrigate 20 million hectares of land with wastewater globally [11]. Development in industrialization and it leads to more demand of freshwater but these industries released many contaminated toxics in environment which caused of contaminated underground water too [12]. Global warming is another issue for agriculture sector, many developing countries are affected by climate change due to poor capacity to deal with it, especially Pakistan which is most affected country by climate change [13-16]. It has not only an impact on agriculture activities due to high temperature and floods [17,18] but it also has impacts on farmers wellbeing and can become a reason of food scarcity in region [19-21]. It is reported that adaption can reduce possible negative impacts of climate change [22]. There is a strong relationship between climate change and farming, so people which are associated with farming generally affected by impacts of climate change [15, 23]. It is not possible to provide help and support to vulnerable farmers for adaption and implementation of good practices without Government involvement [24, 25]. Many researchers acknowledged that farmers are using different techniques to adopt climate changes vulnerability [26] and suggested that there is a crucial need to determine climate change vulnerability, risk perceptions adaptation at a household level in order to minimize impacts of climate change on agriculture $[27,28]$. Pakistan is mainly an agricultural country [29, 30], a major portion of GDP come from this sector.
Agriculture depends on irrigation [31]. Accessibility of water in 2025 is projected $700 \mathrm{~m}^{3} /$ capita. In Pakistan, wastewater directly discharged into open water bodies without prior preliminary treatment and the ratio of wastewater treatment is less than 8 percentage $[32,33]$. Faisalabad city produced $4.09 \mathrm{~m}^{3} / \mathrm{s}$ industrial and domestic sewages [10]. This wastewater is disposed into rivers (Ravi and Chenab) without any treatment and became the main source of underground contamination [34]. Farmers use wastewater there as an alternative to canal water [35]. In district Faisalabad, almost 1000 hectares area is being irrigated with wastewater over last 30 years [36, 7]. Pakistan's vulnerability to the effects of climate change has been cumulative day by day while its contribution to global warming is very less [38]. These days floods, droughts and storms are normal in Pakistan [39], but still there is missing comprehensive policies to deal with such natural disasters [40]. As Pakistan is a developing country, so situation about adaption and vulnerability is not satisfactory and there is very limited research on environmental vulnerability and local-level risk perceptions [41]. The Protection Motivation Theory was used as guiding research on the perspectives of health risks and water conservations [42]. In present age PMT is also used in environmental risks. Climate changes and natural hazards [43]. Regarding climate change these elements are adaption assessment and climate change assessment. Other connecting elements are adaption disincentives/incentives, climate change, subjects' norms and habits are hypothesized to affect the adaption intent of farmers towards climate change [44]. This research will help policymakers to provide support to farmers in their daily life and farming practices. The objectives of this study were i) to investigate the impact of wastewater reuse on crops in Faisalabad District, Pakistan ii) vulnerability, agricultural importance, and severity of flood damage iii) Framer's awareness about impacts of reuse wastewater on crops. iv) adaption of different techniques to deal with climate change.

\section{Material and Method}

\section{Study Area}

Faisalabad district lies in Punjab, Pakistan and had $7,873,910$ inhabitants according to the current census 
of Pakistan [45]. Faisalabad, with a rising population, accounted as the second largest city of the Punjab and the third of Pakistan. The geographical area of Punjab is 20.63 million hectares, out of which $59 \%$ is being cultivated. The province contributes $53 \%$ to the total agricultural GDP (Gross Domestic Product) and $74 \%$ to the total cereal production in the country, Faisalabad contributes a large portion [46]. Nowadays, Faisalabad is known as a strong industrial hub with many factories of textile manufacturing, dye, fertilizer, industrial chemicals, pulp and paper, printing, industrial goods, agricultural equipment and many others. Most of the industrial effluent discharged their waste without any treatment into two main drains Paharang and Madhuana. Paharang Drain eventually discharges to the Chenab River and Madhuana Drain to the Ravi River, both drains are managed by the Irrigation Department [47]. Oxidation ponds established in Faisalabad comprised of anaerobic and facultative ponds. In its surrounding, untreated wastewater had been used for farming crops, vegetables and fodder for the past fifty years [48]. The present study covered five tehsils Chak Jhumra, Faisalabad Sadar, Jaranwala, Samundri and Tandlianwala to analyze farmers' views and determine wastewater quality for irrigation. Fig. 1 shows the map of study area.

\section{Data Sources and Data Analysis}

This study was divided into two phases. In first phase, study was based on farmers' real experience with wastewater irrigation and adaptation techniques for climate change. A semi-structured questionnaire was

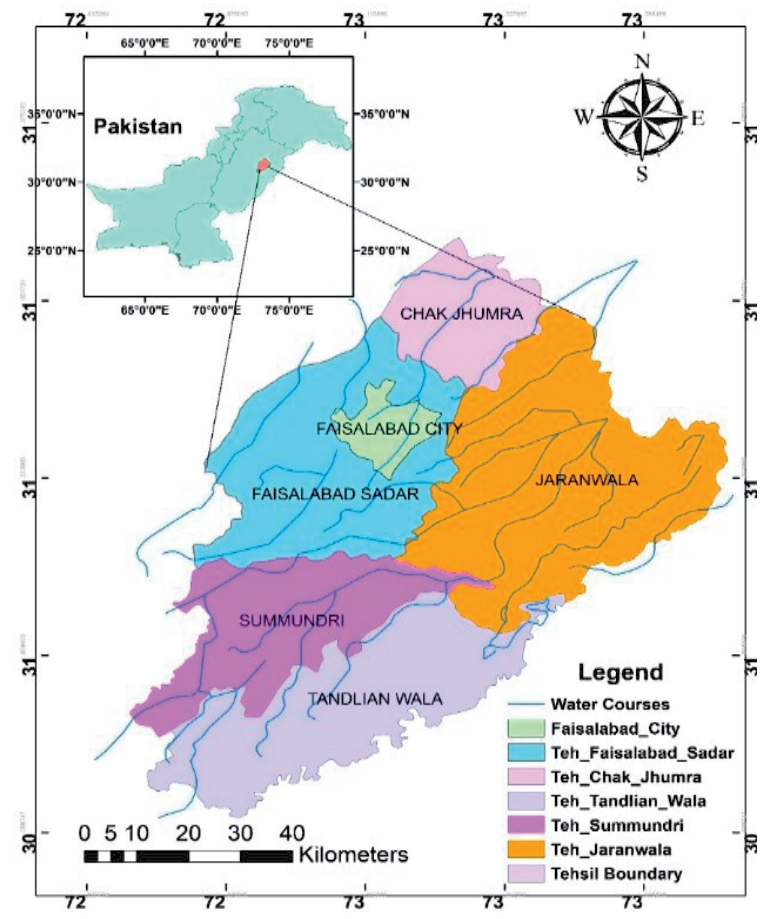

Fig. 1. Study area map. used to collect data collection from farmers of District Faisalabad. Interviewer shared research principles/ ethics and objectives of survey were clearly explained to farmers [49]. Questionnaire consisted of different questions related to demographic information of participants, use of wastewater for irrigation purposes, farmer's livelihood assets, determining factor of climate change and adaption measures in District Faisalabad by following the procedure of other researchers [50]. The questionnaire was translated into Urdu (National Language) so that farmers can understand easily and for illiterate farmers questionnaire were loudly spoken to farmers and the answers were marked by the author himself. It was announced to all farmers that this data is a fully for research purpose and there is no compulsion for them to answer or not [51]. It was voluntary for them to answer if any farmers denied to do the survey, a substitute was included. Five tehsils Chak Jhumra, Faisalabad Sadar, Jaranwala, Samundri and Tandlianwala were selected from District Faisalabad due to its importance and contribution to agriculture fields. A total of 900 completed filled questionnaires were collected from study area. The pre-test was part of this research to avoid any discrepancies. After data collection data was fed into SPSS 24 for further statistical analysis.

In the second phase, different wastewater samples (total $\mathrm{n}=44)$ from industries $(\mathrm{n}=22)$ and sewage $\mathrm{n}=22$ ) were collected from Faisalabad in order to determine the water quality for crop irrigation and compared with standard values. Samples underwent physiochemical and metal analysis of selected parameters (pH, TDS, SS, BOD, COD, As, Cd, Cr, Cu, $\mathrm{Ni}, \mathrm{Pb}$ and $\mathrm{Zn}$ ) according to standard method of APHA (2012) [52].

\section{Metal Pollution Index}

Metal pollution index of all wastewater samples was calculated by using following formula [53] (Pal et al., 2017). Where $W_{i}$ is the unit weight of each parameter which is reciprocal of permissible limit. $M_{i}$ is the monitored value and $S_{i}$ is the standard value of each parameters.

$$
\begin{gathered}
\mathrm{MPI}=\frac{\sum_{i=1}^{n} W_{i} Q_{i}}{\sum_{i=1}^{n} W_{i}} \\
Q_{i}=\sum_{i=1}^{n} \frac{M_{i}}{S_{i}} \times 100
\end{gathered}
$$

\section{Results and Discussion}

Table 1 shows that the total number 900 farmers were interviewed from district Faisalabad (including Chak Jhumra 120, Faisalabad Sadar 55, Jaranwala 250, Samundri 250, Tandlianwala 225). There were some internal possible factors like personal characteristics, 
individual circumstances and farming practices which additionally define as individual farmer's response and adaption capacity, as described by Bryan et al., [25]. Table 1 explained demographic information of all respondents too, most of the interviewed farmers in Chak Jhumra was 93\% male and 7\% female, Faisalabad Sadar $90 \%$ male and $10 \%$ female, Jaranwala $95 \%$ male and $5 \%$ female, Sumundri $92 \%$ male and $8 \%$ female, while in Tandlianwala $87 \%$ male and $13 \%$ female. In all tehsils of district Faisalabad, age of farmers was between 25-35 years, which showed most of them were young and energetic. In Tehsils Chak Jhumra $71 \%$ and Tiandianwala $72 \%$ had primary level education while Faislabad Sadar, Jaranwala and Sumundri maximum

Table 1. Demographic information of participants.

\begin{tabular}{|c|c|c|c|c|c|c|c|}
\hline \multirow[b]{2}{*}{ Characteristics } & \multirow[b]{2}{*}{ Categories } & \multicolumn{6}{|c|}{ Tehsils of district Faisalabad } \\
\hline & & $\begin{array}{c}\text { Chak Jhumra } \\
\%\end{array}$ & $\begin{array}{c}\text { Faisalabad Sadar } \\
\%\end{array}$ & $\begin{array}{c}\text { Jaranwala } \\
\%\end{array}$ & $\begin{array}{c}\text { Samundri } \\
\%\end{array}$ & $\begin{array}{c}\text { Tandlianwala } \\
\%\end{array}$ & Total $(\mathrm{N})$ \\
\hline \multicolumn{2}{|c|}{ Survey Participants (N) } & 120 & 55 & 250 & 250 & 225 & 900 \\
\hline \multirow{2}{*}{ Gender } & Male & 93 & 90 & 95 & 92 & 87 & \\
\hline & Female & 7 & 10 & 5 & 8 & 13 & \\
\hline \multirow{4}{*}{ Age (Years) } & $18-25$ & 10 & 12 & 8 & 7 & 17 & \\
\hline & $25-35$ & 40 & 39 & 42 & 49 & 50 & \\
\hline & $35-45$ & 25 & 18 & 19 & 22 & 19 & \\
\hline & 45-above & 25 & 31 & 31 & 22 & 14 & \\
\hline \multirow{3}{*}{ Education (Years) } & 0 & 10 & 8 & 5 & 4 & 3 & \\
\hline & $1-5$ & 71 & 24 & 45 & 30 & 72 & \\
\hline & 6-more & 19 & 68 & 50 & 66 & 25 & \\
\hline \multirow{4}{*}{$\begin{array}{l}\text { Family Size (Num- } \\
\text { bers) }\end{array}$} & $1-2$ & 16 & 7 & 4 & 6 & 5 & \\
\hline & $3-4$ & 27 & 28 & 30 & 38 & 36 & \\
\hline & $5-6$ & 32 & 44 & 46 & 35 & 43 & \\
\hline & 7-above & 25 & 24 & 19 & 21 & 16 & \\
\hline \multirow{3}{*}{$\begin{array}{l}\text { Farming present land } \\
\text { (Years) }\end{array}$} & $1-10$ & 30 & 28 & 35 & 20 & 17 & \\
\hline & $11-20$ & 46 & 60 & 63 & 75 & 83 & \\
\hline & 21-above & 26 & 12 & 2 & 5 & 0 & \\
\hline \multirow{3}{*}{$\begin{array}{l}\text { Land Preparation } \\
\text { (use) }\end{array}$} & Tractor & 80 & 100 & 84 & 100 & 82 & \\
\hline & Bullocks & 16 & 0 & 6 & 0 & 10 & \\
\hline & Both & 4 & 0 & 10 & 0 & 8 & \\
\hline \multirow{3}{*}{ Plowing per year } & One & 9 & 0 & 0 & 3 & 4 & \\
\hline & Twice & 80 & 86 & 89 & 79 & 90 & \\
\hline & Three-more & 11 & 14 & 11 & 18 & 6 & \\
\hline \multirow{4}{*}{$\begin{array}{l}\text { Frequency } \\
\text { of Irrigation }\end{array}$} & Nil & 0 & 0 & 1 & 0 & 1 & \\
\hline & Weekly & 7 & 13 & 4 & 12 & 8 & \\
\hline & After 2 weeks & 56 & 52 & 52 & 56 & 51 & \\
\hline & Monthly & 37 & 35 & 42 & 32 & 40 & \\
\hline \multirow{4}{*}{ Information Sources } & Media & 22 & 16 & 29 & 14 & 13 & \\
\hline & Other farmers & 60 & 70 & 72 & 80 & 82 & \\
\hline & Own view & 10 & 11 & 20 & 6 & 4 & \\
\hline & Do not know & 8 & 3 & 0 & 0 & 0 & \\
\hline
\end{tabular}

Source: Field Survey 
people had more than 6 years education level. Deressa et al. [54] described that the awareness of the farmer is positively related to farming experience and education. The family size in tehsils was a little high almost all families have more than 2 children while some tehsils have more than five as well that was also providing labor force in farming. The majority of farmers (Chak Jhumra was 46\%, Faisalabad Sadar 60\%, Jaranwala $63 \%$, Sumundri $75 \%$ and in Tandlianwala $83 \%$ ) had more than ten years' experience. In all five tehsils, majority of the respondents used tractors for plowing land. The ratios in all tehsils Chak Jhumra, Faisalabad Sadar, Jaranwala, Sumundri and in Tandlianwala were $80 \%, 100 \%, 84 \%, 100 \%$, and 82 respectively. More than $70 \%$ farmers in all five tehsils plowed their land twice per year. The majority of the respondents irrigated their lands after two weeks. It's very important from where farmers get information for daily life of farming, most of the people said that they got information from their co-farmers and especially old farmers in the same area. It is also approved in literature that farmers' perception to climate change and their impacts accentuate that perception to climatic risks is mediated by farmland characteristics and farmers' demographic assets, for example irrigation availability, amount of cropland, age, farming experience, literacy, and associated factors $[54,55]$. Communication and information sharing are always useful for farmers in decision making and it helps them to adapt better measures for climate change [56]. Earlier studies have broadly covered the significance of demographic characteristics and socioeconomic of farmers concerning climate change adaptation techniques and vulnerability farmers are using at their farmhouses [24, 27].

Table 2 describes situation of water and wastewater used for irrigation purposes. Results showed that most people used to drain and freshwater (Chak Jhumra was $70 \%$, Faisalabad Sadar 70\%, Jaranwala $65 \%$, Sumundri $69 \%$ and in Tandlianwala $62 \%$ ) for irrigation. Many researchers explained that usage of low-quality water for agriculture can have impacts on soils, groundwater quality and consequently on human health [57-59]. As many people were using drains water, we asked another question "Is wastewater cheaper fertilizer than conventional fertilizer?", most people (Chak Jhumra was $100 \%$, Faisalabad Sadar 94\%, Jaranwala 100\%, Sumundri 97\% and in Tandlianwala 93\%) were in favor of "yes". Farmers mostly preferred wastewater due to i) lower water price ii) lower the cost of fertilizer and iii) increase crop production [50]. Farmers were found unaware of possible hazards for wastewater usage, the percentage was as: Chak Jhumra 67\%, Jaranwala 75\%, Sumundri $82 \%$ and in Tandlianwala $89 \%$ while in Faislabad saddar $55 \%$ were aware of hazards by using drains water, same question was asked by Carr, G., et al. [60] in his study. Many farmers said no family was suffering from many diseases but at the same time there were some farmers having few family members with common problems. Economic consideration is of huge importance when evaluating the water reuse potential [61]. A researcher determined the potential of wastewater use to cope with water scarcity in Mekong Delta, Vietnam. They determined that wastewater can reuse on $16 \%$ paddy rice field on 3 crops/years.

Table 2. Use of wastewater for irrigation purposes.

\begin{tabular}{|c|c|c|c|c|c|c|}
\hline \multirow[b]{2}{*}{ Characteristics } & \multirow[b]{2}{*}{ Categories } & \multicolumn{5}{|c|}{ Tehsils of district Faisalabad } \\
\hline & & $\begin{array}{c}\text { Chak Jhumra } \\
\%\end{array}$ & $\begin{array}{c}\text { Faisalabad } \\
\text { Sadar \% }\end{array}$ & $\begin{array}{c}\text { Jaranwala } \\
\% \\
\end{array}$ & $\begin{array}{l}\text { Samundri } \\
\%\end{array}$ & $\begin{array}{c}\text { Tandlianwala } \\
\%\end{array}$ \\
\hline \multirow{3}{*}{ Irrigation (water use) } & Fresh & 12 & 8 & 16 & 16 & 18 \\
\hline & Drains water & 70 & 70 & 65 & 69 & 62 \\
\hline & Both & 18 & 22 & 19 & 15 & 20 \\
\hline \multirow{2}{*}{$\begin{array}{l}\text { Waste water cheaper fertilizer } \\
\text { than conventional fertilizer }\end{array}$} & Yes & 100 & 94 & 100 & 97 & 93 \\
\hline & No & 0 & 6 & 0 & 3 & 7 \\
\hline \multirow{4}{*}{$\begin{array}{l}\text { Reasons for farmers to } \\
\text { wastewater for irrigation? }\end{array}$} & Lower water price & 8 & 1 & 3 & 10 & 9 \\
\hline & Lower the cost of fertilizer & 4 & 1 & 4 & 10 & 4 \\
\hline & Increase crop production & 5 & 2 & 6 & 4 & 6 \\
\hline & All above & 83 & 96 & 87 & 76 & 81 \\
\hline \multirow{2}{*}{$\begin{array}{l}\text { Do you know potential hazards } \\
\text { caused by wastewater? }\end{array}$} & Yes & 33 & 55 & 25 & 18 & 11 \\
\hline & No & 67 & 45 & 75 & 82 & 89 \\
\hline \multirow{2}{*}{$\begin{array}{l}\text { Is your any family member } \\
\text { suffering from any disease? }\end{array}$} & Yes & 11 & 18 & 3 & 2 & 15 \\
\hline & No & 89 & 82 & 97 & 98 & 85 \\
\hline
\end{tabular}

Source: Field Survey 
The fertilizer property (22\% Nitrogen, $14 \%$ phosphorus) eradicates the demand for artificial fertilizers. He analyzed that such program contributes to pollution control [62].

Table 3 describes farmers' assets for supporting their livelihood. It presented the assets owned by the farmers such as motorbike, bicycle, tractor/plow, spraying device, tube well, children go to school, electric generator, gas generator, air conditioner, car and pets (dog, horse, etc). In these five tehsils of district Faisalabad of Pakistan, many farmers owned these all above mentioned assets related to their farming life. Almost half of farmers owned their personal tractor for land preparation. Many of other luxuries like air conditioners, car, generators, tube wells and tubes in the study area were not available to farmers as it approved their bad economic conditions [54, 63]. It is assumed that access to latest technology for farming stimulates growth in agriculture and help in poverty reduction [38]. Farmers having enough resources were more willing to reduce risk and had more capacity to adapt [54]. It can be described as farmers with more capital regarded themselves safer and have more capacity to bear negative impacts of change in climatic conditions while poor economic conditions forced the farmers to sacrifice consumer health [64]. Another author explained that small farmers are always at risk due to natural disasters like droughts, heavy precipitation and floods etc. [40].

Fig. 2 describes the perception of farmers to climate change in District Faisalabad. The effects of climatic have become progressively apparent over the past few decades [65]. The main indicators that were included to check perception were flood, irrigation, agriculture, droughts, soils Issues, drinking water in agriculture area, communication, transportation to agriculture land, animal diseases and crop pests as described by Fahad and Wang (2018a) [38]. As per response from farmers flood rate in Tiandianwala and Chuk Jumra is high while rest of tehsils put it in moderate or low rate in

Table 3. Farmer's livelihood assets.

\begin{tabular}{|c|c|c|c|c|c|c|}
\hline \multirow{2}{*}{\multicolumn{2}{|c|}{ Characteristics }} & \multicolumn{5}{|c|}{ Tehsils of district Faisalabad } \\
\hline & & Chak Jhumra \% & Faisalabad Sadar \% & Jaranwala \% & Samundri \% & Tandlianwala \% \\
\hline \multirow{2}{*}{ Motorbike } & No & 8 & 14 & 10 & 2 & 17 \\
\hline & Yes & 92 & 87 & 90 & 98 & 83 \\
\hline \multirow{2}{*}{ Bicycle } & No & 12 & 25 & 16 & 7 & 19 \\
\hline & Yes & 88 & 75 & 84 & 93 & 81 \\
\hline \multirow{2}{*}{ Tractor/Plow } & No & 45 & 35 & 33 & 47 & 55 \\
\hline & Yes & 55 & 65 & 77 & 53 & 45 \\
\hline \multirow{2}{*}{ Spraying Device } & No & 95 & 0 & 30 & 0 & 35 \\
\hline & Yes & 5 & 100 & 70 & 100 & 65 \\
\hline \multirow{2}{*}{ Tube Well } & No & 85 & 90 & 88 & 45 & 14 \\
\hline & Yes & 15 & 10 & 12 & 55 & 86 \\
\hline \multirow{2}{*}{ Children go to School } & No & 0 & 0 & 0 & 1 & 2 \\
\hline & Yes & 100 & 100 & 100 & 99 & 98 \\
\hline \multirow{2}{*}{ Electric Generator } & No & 100 & 98 & 96 & 99 & 96 \\
\hline & Yes & 0 & 2 & 4 & 1 & 4 \\
\hline \multirow{2}{*}{ Gas Generator } & No & 100 & 96 & 100 & 98 & 100 \\
\hline & Yes & 0 & 4 & 0 & 2 & 0 \\
\hline \multirow{2}{*}{ Air conditioner } & No & 100 & 95 & 99 & 96 & 100 \\
\hline & Yes & 0 & 5 & 1 & 4 & 0 \\
\hline \multirow{2}{*}{ Car } & No & 99 & 91 & 96 & 92 & 99 \\
\hline & Yes & 2 & 9 & 4 & 8 & 1 \\
\hline \multirow{2}{*}{ Pets (Dog, Horse, etc) } & No & 0 & 10 & 0 & 7 & 0 \\
\hline & Yes & 100 & 90 & 100 & 93 & 100 \\
\hline
\end{tabular}

Source: Field Survey 


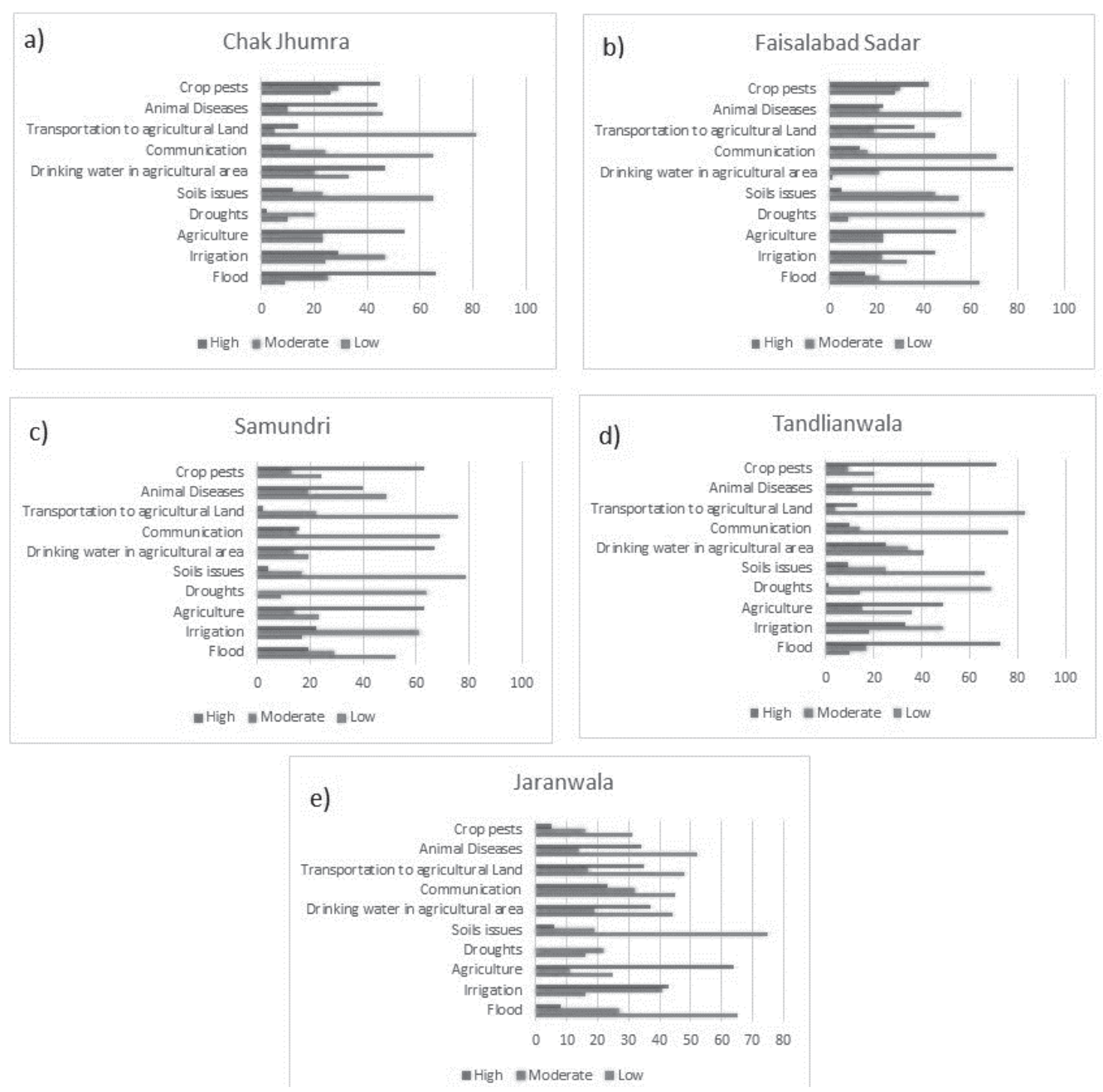

Fig. 2. Determining factor (\%) of Climate Change, a) Chak Jhumra, b) Faisalabad Sadar c) Samundri, d) Tandlianwala, e) Jaranwala (Data Source: Field Survey).

study. So, flood can be the main threat to the farmers of these both tehsils. It is reported that if there are number of floods, droughts and high temperatures in any area that might have impacts on farmers' life [27,66]. Pakistan is a developing country, like other developing countries, major portion of the Pakistan population is living in poor conditions in natural disaster area especially farmers [38] (Fahad, et al., 2018a). Pakistan faced destructive floods in history [67] like 2010, 2011 and 2014 which caused damage to livestock, forestry, infrastructure, fisheries, animal sheds, fertilizers, loss of approximately 250000 farms households and 1 million cultivated lands [68]. If number of floods and droughts increased it will lead to increase the likelihood of poor yields, crop failure and livestock mortality [69].

In Present study adaptation techniques were based on the following parameters: change crop type, change fertilizer, change crop variety, store water, plant shaded trees, stop cutting trees, change seed quality, change irrigation and change pesticide as described by Fahad and Wang [38] (2018a) (Fig. 3). It is reported in the literature that similar kinds of adaptation measures like crop types, change plantation time, changing input mix and changing varieties being adopted by farmers in different regions of Pakistan [70]. It is also reported in recent times, crop production reduced may due to climate change, different plant diseases, irrigation issues or poverty [38]. The vulnerability investigation showed that small farmers were relatively vulnerable to adopt climate changes [71]. The impact of climatic risks on family food, income and security were significantly supposed stronger by low-resource-endowed existence farmers [72]. As per another study conducted in Africa, they said it is the first step of adaptation toward climate change [54]. There are many researchers already described impacts of climates changes on crop productions [73]. Pakistan is an agricultural country and currently reducing its crop production due to climate issues [74]. So, it is necessary for farmers to learn about climates risk and adoptions conditions, so that they can minimize risk rate and maximize their crop productions, at the same time it's very necessary to have insurance schemes for farmers to help them in disaster situations Table 4 shows the results of descriptive statistical and correlation coefficient of this study of with selected variables (gender, age, education, farming experience, 


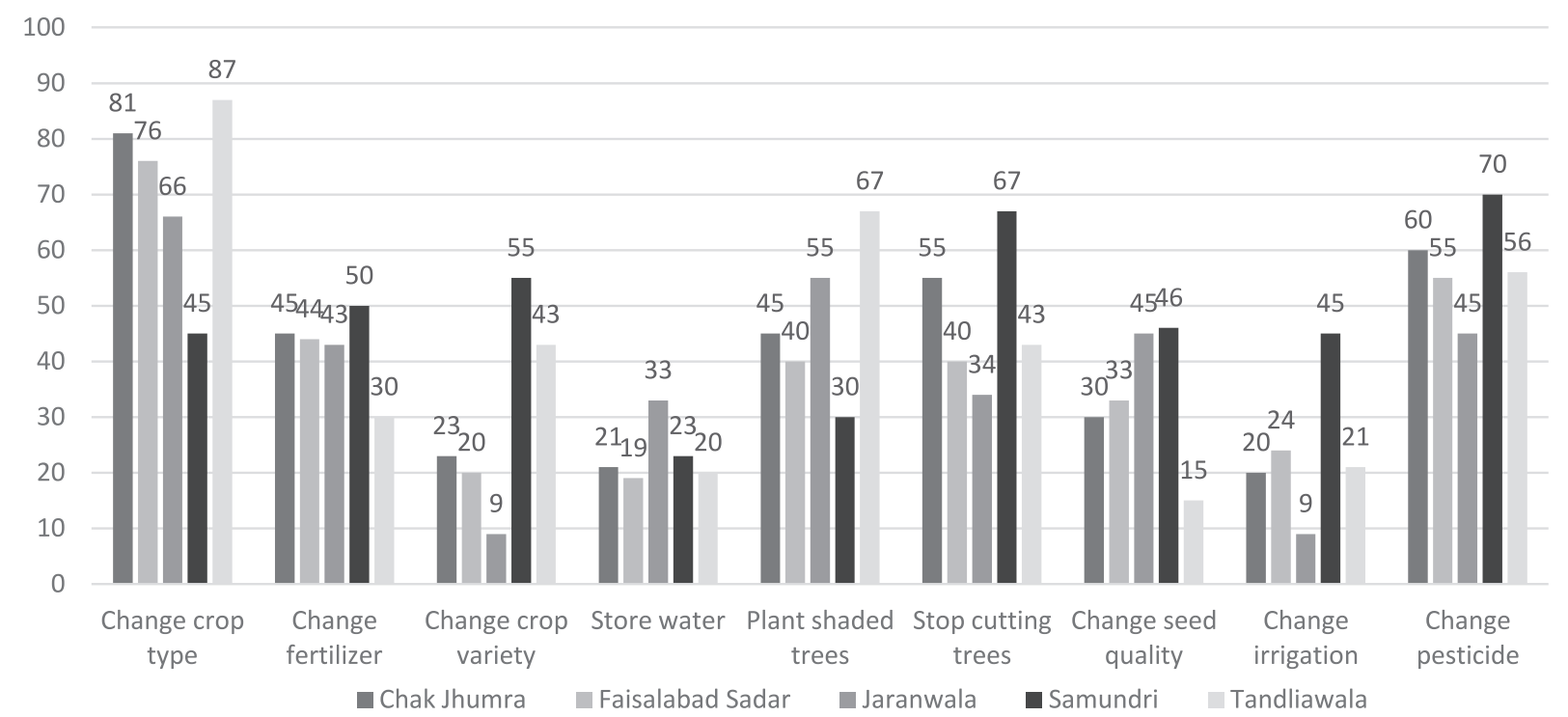

Fig. 3. Adaption strategies/measures by farmers in District Faisalabad (Data Source: Field Survey).

livelihood assets (LA), determining of climate change (DCC), Adaption Measures (AM)). It is a tool to check the relation between two or more variables. The values of correlation are between +1.00 to -1.00 . The strength of correlation is determined by the magnitude of the number with 1 being maximum. The current study correlation of Determining of Climate Change (DCC) with age and farming experience is highly significant with correlation values 0.48 and 0.42 respectively. Adaption Measures (AM) correlation values with age and farming experience were 0.49 and 0.75 respectively. Other variables livelihood Assets (LA) were also correlated with Determining of Climate Change (DCC) and Adaption Measures (AM). All variables were found significant with weak to moderate correlation among all selected variables (Table 5).

\section{Analysis of Wastewater Parameters}

Industrial effluents and sewage water samples, including Madhuana drain and Pharang drain were analyzed for physicochemical and metal analysis.
Table 5 showed the concentrations of all parameters in sewage and industrial effluent comparing with PEQs. The average concentration of parameters including $\mathrm{pH}$ (10.2 \pm 1.51 and $8.11 \pm 0.57)$, suspended solids (314.7 \pm 86.4 and 179.9 \pm 33.07$)$, TDS (5045.35 \pm 1597 and $2969 \pm 874)$, COD $\quad(3247.3 \pm 3124.8$ and $383.8 \pm 126.1), \quad$ BOD (955.8 \pm 920.3 and $122.06 \pm 42.2)$ in sewage and industrial water respectively were higher than their acceptable limit. Increased value of $\mathrm{pH}$ in water can be reason for decreasing metal toxicity. Industrial and Municipal wastewater effluent discharge caused increased TDS in water [76,77]. This increased TDS can be reason of increase COD and BOD in water which ultimately influence on DO indicated and reduction the presence of increased inorganic and organic matter [78-80]. $\mathrm{BOD} / \mathrm{COD}$ ratio at all sampling stations shows a lower level which implies poor biodegradability. TDS concentration at all sampling stations shows a very high level exceeding permissible limit for irrigation unless an expensive desalination process is applied. All the metals

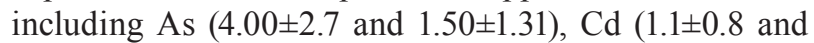
$0.80 \pm 0.84), \mathrm{Cr}(1.42 \pm 1.72$ and $1.95 \pm 0.59), \mathrm{Cu}(8.67 \pm 5.13$

Table 4. Correlation coefficient of selected variables .

\begin{tabular}{|c|c|c|c|c|c|c|c|c|}
\hline Variables & Standard Deviation & 1 & 2 & 3 & 4 & 5 & 6 & 7 \\
\hline Gender & 0.72 & 1 & & & & & & \\
\hline Age & 0.56 & -0.08 & 1.00 & & & & & \\
\hline Education & 0.66 & -0.06 & $\mathbf{0 . 7 9}^{* *}$ & 1.00 & & & & \\
\hline Farming Experience & 0.78 & 0.24 & $\mathbf{0 . 3 5}^{*}$ & $\mathbf{0 . 7 3}^{* *}$ & 1.00 & & & \\
\hline Livelihood assets (LA) & 0.74 & -0.12 & $\mathbf{0 . 4 5}^{*}$ & $\mathbf{0 . 6 4}^{* *}$ & $0.36^{*}$ & 1.00 & & \\
\hline Determining of Climate Change (DCC) & 0.67 & -0.07 & $\mathbf{0 . 4 8}^{* *}$ & $\mathbf{0 . 4 0}^{* *}$ & $\mathbf{0 . 4 2}^{* *}$ & $\mathbf{0 . 4 0}^{*}$ & 1.00 & \\
\hline Adaption Measures (AM) & 0.71 & $0.44^{*}$ & $\mathbf{0 . 4 9}^{* *}$ & $\mathbf{0 . 7 5}^{* *}$ & $\mathbf{0 . 6 3}^{* *}$ & $\mathbf{0 . 5 7}^{* *}$ & $\mathbf{0 . 5 5}^{* *}$ & 1.00 \\
\hline
\end{tabular}

Notes: $* * \mathrm{p}<0.01, * \mathrm{p}<0.05$ (two-tailed test). $\mathrm{N}=900$ 
Table 5. Average concentrations of sewage and industrial effluents.

\begin{tabular}{|c|c|c|c|c|c|c|}
\hline \multirow{2}{*}{ Sr. \# } & \multirow{2}{*}{ Parameters } & \multicolumn{2}{|c|}{ Industrial Wastewater } & \multicolumn{2}{c|}{ Sewage Wastewater } & \multirow{2}{*}{ PEQs (2016) } \\
\cline { 3 - 6 } & & Mean \pm SD & Range & Mean \pm SD & Range & $6-9$ \\
\hline 1 & $\mathrm{pH}$ & $10.2 \pm 1.51$ & $7.4-13.5$ & $8.11 \pm 0.57$ & $7.48-9.7$ & 200 \\
\hline 3 & SS (mg/L) & $314.7 \pm 86.4$ & $140-516$ & $179.9 \pm 33.07$ & $119-233$ & 3500 \\
\hline 4 & TDS (mg/L) & $5045.35 \pm 1597$ & $1856-7520$ & $2969 \pm 874$ & $1337-4083$ & 80 \\
\hline 5 & BOD (mg/L) & $955.8 \pm 920.3$ & $123-4061$ & $122.06 \pm 42.2$ & $63-219$ & 19 \\
\hline 6 & COD (mg/L) & $3247.3 \pm 3124.8$ & $415-13394$ & $383.8 \pm 126.1$ & $206-641$ & 150 \\
\hline 7 & Coliform (mg/L) & $8015 \pm 2584$ & $3600-14400$ & $8066 \pm 2318$ & $4000-14400$ & -- \\
\hline 8 & Cadmium (mg/L) & $1.1 \pm 0.8$ & $0.21-2.42$ & $0.80 \pm 0.84$ & $0.04-2.31$ & 0.1 \\
\hline 9 & Chromium (mg/L) & $1.42 \pm 1.72$ & $0.11-4.76$ & $1.95 \pm 0.59$ & $0.78-2.94$ & 1.0 \\
\hline 10 & Copper (mg/L) & $8.67 \pm 5.13$ & $1.75-21.34$ & $1.91 \pm 1.02$ & $0.06-4.32$ & 1.0 \\
\hline 11 & Lead (mg/L) & $2 \pm 2.29$ & $0.12-7.56$ & $0.35 \pm 0.11$ & $0.13-0.59$ & 0.5 \\
\hline 12 & Nickel (mg/L) & $9.5 \pm 4.4$ & $1.45-21.2$ & $3.90 \pm 1.65$ & $2.13-8.69$ & 1.0 \\
\hline 13 & Zinc (mg/L) & $10.94 \pm 6.47$ & $0.97-26.11$ & $15.7 \pm 5.01$ & $4.67-23.4$ & 5.0 \\
\hline
\end{tabular}

PEQs = Pakistan Environmental Quality Standards

and 1.91 \pm 1.02$), \mathrm{Pb}(2 \pm 2.29$ and $0.35 \pm 0.11), \mathrm{Ni}(9.5 \pm 4.4$ and $3.90 \pm 1.65), \mathrm{Zn}(10.94 \pm 6.47$ and $15.7 \pm 5.01)$ in sewage and industrial water were found more than its acceptable limits of PEQs. Heavy metals are accountable for the mutagenic and lethal activities and have competence to cross the cell membrane [81]. A fertilizer industry of Pakistan was examined for heavy metal and come with result that chromium and lead were found more than their acceptable limits and results conventional that wastewater from industry is potential for changing the chemistry of different water resources [78]. A study investigated that quality of industrial and sewage effluent at Faisalabad inappropriately and even not a single industry was obeying the National Environmental Quality Standards (NEQs) for waste disposal [10]. Rivers that pass-through Faisalabad are Ravi and Chenab, they slowly becoming polluted due to release of untreated wastewater by Madhuana and Paharang drains. It makes water unfit for drinking purposes and can be a reason for many health risks. Al-Musharafi et al. [82] stated that cadmium and lead are currently being considered worldwide due to toxicity. Wastewater irrigation may provide advantage to meet desertification, but they could have social concerns about due to presence of harmful compounds in wastewater [83]. Heavy metals accumulation with wastewater irrigated soils has been stated by numerous studies $[84,85]$. The most toxic metals including $\mathrm{Hg}$, $\mathrm{Cr}, \mathrm{Cd}$ and $\mathrm{Pb}$ were documented for creating harmful effects on humans and environment [85]. Azeem [86] investigated the industries effluent in Kot Lakhpat industrial zone, Lahore higher concentration of $\mathrm{Cr}$, $\mathrm{Cd}, \mathrm{Fe}, \mathrm{Pb}$ and $\mathrm{Zn}$ in effluent were reported. Likewise,
Tariq et al. [59] determine that industrial effluent contained high values of different heavy metals like $\mathrm{Cr}$ (51.70 ppm), $\mathrm{Fe}(14.54 \mathrm{ppm})$ and $\mathrm{Pb}(0.646 \mathrm{ppm})$ in Peshawar and use of such industrial effluent without appropriate administration could pose severe risk to soil and food quality.

\section{Metal Pollution Index (MPI)}

Pollution index of wastewater was analyzed by seven metals including $\mathrm{As}, \mathrm{Cd}, \mathrm{Cr}, \mathrm{Cu}, \mathrm{Ni}, \mathrm{Pb}$ and $\mathrm{Zn}$. This study showed that the values of all metals in almost all samples increased the permissible limit of PEQs. In Fig. 4, results showed out of 22 industrial sites, 11 industries have MPI more than 1000. Three sites have MPI between 500-1000 while other seven sites have 100-500 MPI values. Although all the sites were above the safe limit due to heavy metal toxicity. In sewage water samples out of 22 sites, six sites have MPI more than 100, while 12 sites have MPI $>100$ and other remaining 4 have less than 100 MPI indicating low metal toxicity in wastewater. Overall metal toxicity is higher in industrial and sewage water and farmers used this toxic water for crop irrigation. Kumari et al. [87] estimated the HPI of two selected pharmaceutical industries in Lucknow and found HPI 52.14 and 108.7 respectively, which is less than the present study. Industrial and Domestic effluent generates $4.09 \mathrm{~m}^{3} / \mathrm{s}$ and their toxic pollutants leakage in to contaminate groundwater and soil and causing health related issues in Faisalabad [6] (Srinivasan and Reddy 2009). Chenab and Ravi rivers obtain the untreated wastewater of Pharang and Madhuana drains. Faisalabad industries 


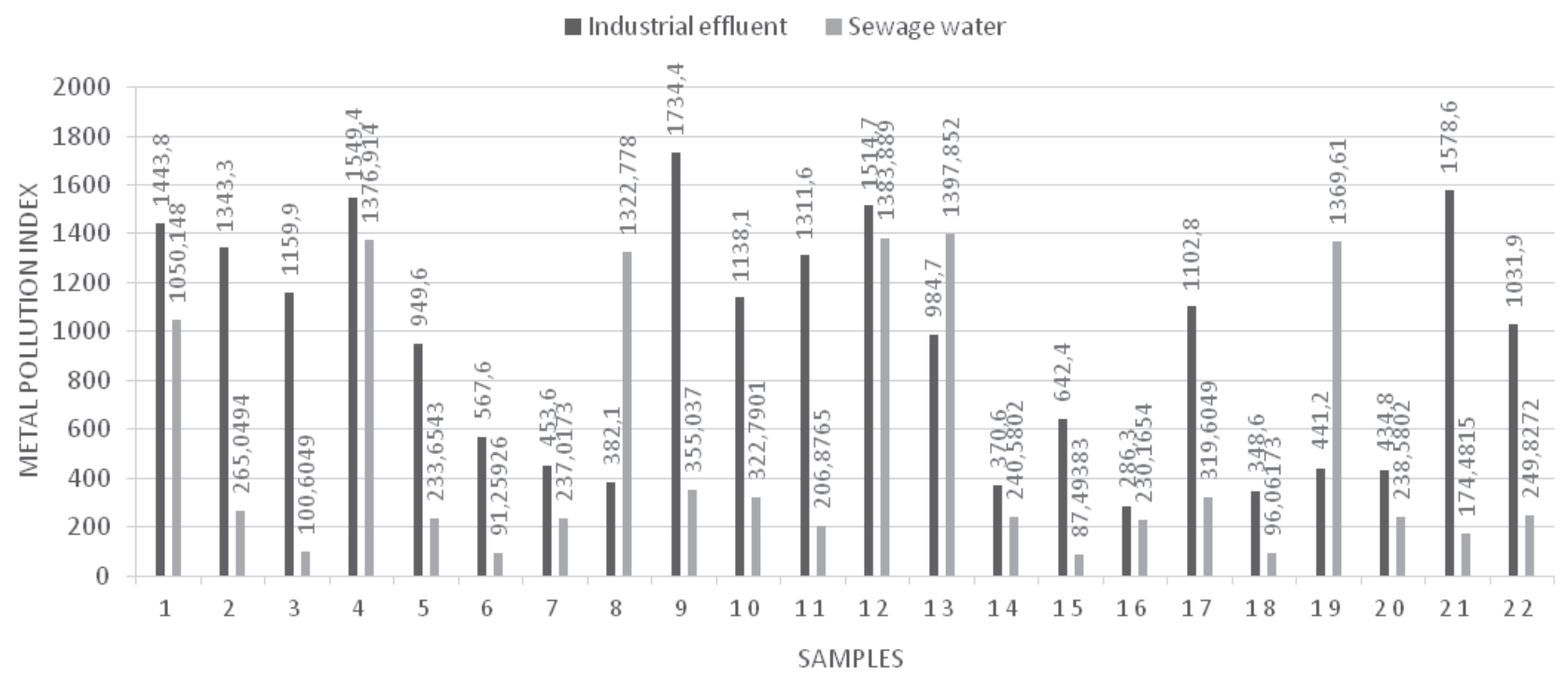

Fig. 4. Metal Pollution Index for industrial and sewage water.

include dyeing, textile, sugar mills, hospital laboratory, fertilizers, acids, batteries, chemicals and processing units which release their toxic effluent in drains without any prior treatment, even at primary level. Another author analyzed the heavy metal pollution in industrial wastewater and explained that ghee and textile industry has less metal concentration, tannery and $\mathrm{Ni}-\mathrm{Cr}$ plating industry has medium although in battery industry $(\mathrm{Fe})$ has uppermost pollution level and crossed all standard limits [88].

\section{Conclusions}

The study analyzed the situation of farmers' awareness about reusing wastewater, risk perception and adaptation for climate change. Farmers had a strong awareness of the fertility value of wastewater, but they did not have enough awareness about the impact of polluted water on crops. Wastewater released by industry is polluted and has negative impacts on agriculture. Farmer's life is not good enough to deal with natural disasters. Small farmers had more threats as compared to well settle farmers. The results described that droughts, temperature, floods, variation are the major risks linked with climate change and it is adversely affecting agriculture. Farmers used some techniques against climate change like irrigation, seeds, fertilizer and crops. Industrial and sewage wastewater quality of Faisalabad was investigated and concluded that this was creating an alarming situation for local people's health and environment. The high metal pollution index showed heavy effluent discharge from industries and putting pressure on groundwater resources as well. To overcome amount of wastewater and meet irrigation scarcity in semi-arid area, the reuse of wastewater after primary treatment is the best practice. Many other management strategies including bacterial inoculation and improving water quality factoring yield, cost and input can give new research direction for economically viable management of resources. The study will help to support the implementation of proper monitoring and public policies to ensure the integrated and sustainable water development and to minimize the health hazards in the study area and it will to policymaker to provide support to farmers in their daily life and farming practices. It is not possible to provide help and support to vulnerable farmers for adaption and implementation of good practices without Government involvement. This study was carried out in one of important agricultural and industrial area Faisalabad Pakistan and results can be used for policy implications for other same kind of agricultural area. It is suggested to cover more larger area and data about diseases of study due to contaminated water maybe be included for future research.

\section{Acknowledgement}

The author would like to thanks to Editor, Reviewers and all coauthors for their contribution to make this article better for publication. This research was supported by Xiangtan University Startup Research Grant (03KZ_KZ0806803).

\section{Conflict of Interest}

The authors declare no conflict of interest.

\section{References}

1. HUI T., XIUJUAN L., QIFA S., QIANG L., ZHUANG K., YAN G. Evaluation of Drinking Water Quality Using 
the Water Quality Index (WQI), the Synthetic Pollution Index (SPI) and Geospatial Tools in Lianhuashan District, China. Polish Journal of Environmental Studies, 30 (1), 2020.

2. SOHAIL M.T., MAHFOOZ Y., AZAM K., YEN Y., GENFU L., FAHAD S. Impacts of urbanization and land cover dynamics on underground water in Islamabad, Pakistan. Desalination and Water Treatment, 159, 402, 2019.

3. LI RAN, YI-MING KUO Effects of Shallow Water Table Depth on Vegetative Filter Strips Retarding Transport of Nonpoint Source Pollution in Controlled Flume Experiments. International Journal of Environmental Research, 1, 2021.

4. BATOOL S., IDREES M., AL-WABEL M. I., AHMAD M., HINA K., ULLAH H., CUI L., HUSSAIN Q. Sorption of $\mathrm{Cr}$ (III) from aqueous media via naturally functionalized microporous biochar: Mechanistic study, Microchemical Journal, 144, 242, 2019.

5. IDREES M., BATOOL S., ULLAH H., HUSSAIN Q., AL-WABEL M.I, AHMAD M., HUSSAIN A., RIAZ M., OK Y.S., KONG J. Adsorption and thermodynamic mechanisms of manganese removal from aqueous media by biowaste-derived biochars, Journal of Molecular Liquids, 266, 373, 2018a.

6. SRINIVASAN J.T., REDDY V.R. Impact of irrigation water quality on human health: A case study in India. Ecological Economics, 68 (11), 2800, 2009.

7. DRECHSEL P., SCOTT C.A., RASCHID-SALLY L., REDWOOD M., BAHRI A. Wastewater Irrigation and Health: Assessing and Mitigating Risk in Low-Income Countries. London, UK: Earthscan, 2010.

8. HANJRA M.A., BLACKWELL J., CARR G., ZHANG F., JACKSON T.M. Wastewater irrigation and environmental health: implications for water governance and public policy. International Journal Of Hygiene and Environmental Health, 215 (3), 255, 2012.

9. SCOTT A.C., J.A. ZARAZ A, LEVINE G. Urbanwastewater reuse for crop production in the watershort Guanajuato river basin, Mexico. IWMI Research report 43. Colombo, Sri-Lanka: International Water Management Institute, 2010.

10. YAMIN M., NASIR A., SULTAN M., ISMAIL W.I. W., SHAMSHIRI R., AKBAR F.N. Impact of sewage and industrial effluents on water quality in Faisalabad, Pakistan. Advances in Environmental Biology, 9 (18), 53, 2015.

11. RASCHID-SALLY L. JAYAKODY P. Drivers and characteristics of wastewater agriculture in developing countries - results from a global assessment. International Water Management Institute, 2008.

12. SOHAIL M.T., MAHFOOZB Y., AFTABC R., YEND Y., TALIBE M.A., RASOOLF A. Water quality and health risk of public drinking water sources: a study of filtration plants installed in Rawalpindi and Islamabad, Pakistan. Desalination and Water Treatment, 181, 239, 2020.

13. KURUKULASURIYA P., ROSENTHAL S. Climate Change and Agriculture: A Review Of Impacts and Adaptations. Paper No. 91 in Climate Change Series. The World Bank, Washington D.C. 2003.

14. SKOUFIAS E., RABASSA M., OLIVIERI S. The poverty impacts of climate change. Economic Premise, vol. 5622 Worldbank, 2001.

15. ALI A., ERENSTEIN O. Assessing farmer use of climate change adaptation practices and impacts on food security and poverty in Pakistan. Climate Risk Management, 16, $183,2017$.

16. MENIKE L.M.C.S., ARACHCHI K.K. Adaptation to climate change by smallholder farmers in rural communities: Evidence from Sri Lanka. Procedia Food Science, 6, 288, 2016.

17. IPCC. Climate change 2014: impacts, adaptation, and vulnerability. 360 Part a: global and sectoral aspects. Contribution of Working Group II to the Fifth Assessment Report of the Intergovernmental Panel on Climate Change. Intergovernmental Panel on Climate Change 2014.

18. SHINBROT X.A., JONES K.W., RIVERA-CASTAÑEDA A., LÓPEZ-BÁEZ W., OJIMA D.S. Smallholder Farmer Adoption of Climate-Related Adaptation Strategies: The Importance of Vulnerability Context, Livelihood Assets, and Climate Perceptions. Environmental management, 1, 2019.

19. ALAM U., SAHOTA P. JEFFREY P. Irrigation in the Indus basin: A history of unsustainability? Water Science and Technology 7, 211, 2007.

20. SOHAIL M.T., ULLAH S., MAJEED M.T. Pakistan management of green transportation and environmental pollution: a nonlinear ARDL analysis. Environmental Science and Pollution Research, 1, 2021.

21. LOBELL D.B., GOURDJI S.M. The influence of climate change on global crop productivity. Plant Physiol. 160, 1686, 2012.

22. ADGER W.N., KELLY P.M. Social vulnerability to climate change and the architecture of entitlements. Mitigation and Adaptation Strategies for Global Change, 4 (3-4), 253, 1999.

23. GREENOUGH G., MCGEEHIN M., BERNARD S.M., TRTANJ J., RIAD J., ENGELBERG D. The potential impacts of climate variability and change on health impacts of extreme weather events in the United States. Environmental Health Perspectives, 109 (suppl 2), 191, 2001.

24. BRYAN E., DERESSA T.T., GBETIBOUO G.A., RINGLER C. Adaptation to limate change in Ethiopia and South Africa: options and constraints. Environmental Science Policy, 12, 413, 2009.

25. BRYAN E., RINGLER C., OKOBA B. Adapting agriculture to climate change in Kenya: household strategies and determinants. Journal of environmental management, 114, 26, 2013.

26. RAFIAT OGUNPAIMO O., OYETUNDE-USMAN Z., SURAJUDEEN J. Impact of Climate Change Adaptation on Household Food Security in Nigeria-a Difference-inDifference Approach. Sustainability, 13 (3), 1444, 2021.

27. ABID M., SCHEFFRAN J., SCHNEIDER U.A., ASHFAQ M. Climate change vulnerability, adaptation and risk perceptions at farm level in Punjab, Pakistan. Science of the Total Environment, 547, 447, 2016.

28. SOHAIL M.T., DELIN H., TALIB M.A., XIAOQING X., AKHTAR M.M. An Analysis of Environmental Law in Pakistan-policy and Conditions of Implementation. Research Journal of Applied Sciences, Engineering and Technology, 8 (5), 644, 2014a.

29. MUGHAL M.A. Rural urbanization, land, and agriculture in Pakistan. Asian Geographer, 36 (1), 81, 2019.

30. SOHAIL M.T., DELIN H., SIDDIQ A. Indus Basin Waters A Main Resource of Water in Pakistan: An Analytical Approach. Current World Environment, 9 (3), 670, 2014b.

31. FIAZ S., MOBEEN N., NOOR M.A., MUDDASSIR M., MUBUSHAR M. Implications of Irrigation Water Crisis 
on Socioeconomic Condition of Farmers in Faisalabad District, Punjab, Pakistan. Asian Journal of Agricultural Extension, Economics Sociology, 10 (1), 1, 2016.

32. AKHTAR S., AHMAD S., HUIFANG W., SHAHBAZ A., GHAFOOR A., IMRAN S., ZAFAR A. An analysis of wastewater irrigation practices and its impacts on the livelihood generation and food chain contamination in Faisalabad District, Pakistan, ISABB Journal of Health and Environmental Sciences, 5 (4), 33, 2018.

33. MAHFOOZ Y., YASAR A., SOHAIL M.T., TABINDA A.B., RASHEED R., IRSHAD S., YOUSAF B. Investigating the drinking and surface water quality and associated health risks in a semi-arid multi-industrial metropolis (Faisalabad), Pakistan. Environmental Science and Pollution Research, 1, 2019.

34. REHMAN K., ASHRAF S., RASHID U., IBRAHIM M., HINA S., IFTIKHAR T., RAMZAN S. Comparison of proximate and heavy metal contents of vegetables grown with fresh and wastewater. Pak. J. Botany, 45, 391, 2013.

35. ANWAR H.N., NOSHEEN F., HUSSAIN S., NAWAZ W. Socio-economics consequences of reusing wastewater in agriculture in Faisalabad. Pakistan Journal of Life and Social Sciences, 8 (2), 102, 2010.

36. BAIG I.A., ASHFAQ M., HASSAN I., JAVED M.I., KHURSHID W., ALI A. Economic impacts of wastewater irrigation in Punjab, Pakistan, J. Agric. Res., 49 (2), 2011.

37. BAIG A., AMJAD S. Impact of climate change on major crops of Pakistan: a forecast for 2020. Pakistan Bus. Rev. 15, 600, 2014.

38. FAHAD S., WANG J. Farmers' risk perception, vulnerability, and adaptation to climate change in rural Pakistan. Land use policy, 79, 301, 2018a.

39. MUELLER V., GRAY C., KOSEC K. Heat stress increases 420 long-term human migration in rural Pakistan. Nature climate change, 4 (3), 182, 2014.

40. QASIM S., KHAN A.N., SHRESTHA R.P., QASIM M. Risk perception of the people in the flood prone Khyber Pakhtunkhwa province of Pakistan. International Journal of Disaster Risk Reduction.14, 373, 2015.

41. HUSSAIN S.S., MUDASSER M. Prospects for wheat production under changing climate in mountain areas of Pakistan - An econometric analysis. Agricultural Systems, 94 (2), 494, 2007.

42. FLOYD D.L., PRENTICE-DUNN S., ROGERS R.W. A meta-analysis of research on protection motivation theory. Journal of applied social psychology, 30, 407, 2000.

43. DANG H.L., LI E., BRUWER J., NUBERG I. Farmers' perception of climate variability and barriers to adaptation: Lessons learned from an exploratory study in Vietnam. Mitigation and adaptation strategies for global change. 19, 531, 2014.

44. DANG L.H., LI E., BRUWER J. Understanding climate change adaptive behaviour of farmers: An integrated conceptual framework. Clim. Chang. Impacts Responses, 3, 255, 2012.

45. PAKISTAN BUREAU OF STATISTIC. http://www.pbs. gov.pk/sites/default/files/PAKISTAN\%20TEHSIL\%20 WISE\%20FOR\%20WEB\%20CENSUS_2017.pdf 2017.

46. BADAR H., JAVED M.S., ALI A., BATOOL Z. Production and marketing constraints limiting sunflower production in Punjab (Pakistan). Int. J. Agric. Biol. 4, 267, 2002.

47. IJAZ, G. SHABIR, Q.M. KHAN, M. AFZAL, Enhanced remediation of sewage effluent by endophyte-assisted floating treatment wetlands, Ecological Engineering, 84, $58,2015$.
48. ALI H.Q., FAROOQ A., AHMED M. Monitoring the wastewater treatment efficiency of oxidation ponds at Chokera, Faisalabad. Mehran university research journal of engineering technology 36 (4), 987, 2017.

49. BOGNER ALEXANDER, BEATE LITTIG, WOLFGANG MENZ, eds. Interviewing experts. Springer, 2009.

50. MOJID M.A., WYSEURE G.C.L., BISWAS S.K., HOSSAIN A.B.M.Z. Farmers' perceptions and knowledge in using wastewater for irrigation at twelve peri-urban areas and two sugar mill areas in Bangladesh. Agricultural Water Management, 98 (1), 79, 2010.

51. MCCUSKER K., GUNAYDIN S. Research using qualitative, quantitative or mixed methods and choice based on the research. Perfusion, 30 (7), 537, 2015.

52. APHA. Standard Methods for the Examination of Water and Waste Water, 17th edition, American Public Health Association, Washington DC., 2012.

53. PAL R., DUBEY R.K., DUBEY S.K., SINGH A.K., Assessment of Heavy Metal Pollution through Index Analysis for Yamuna Water in Agra Region, India, Int. J. Curr. Microbiol. App. Sci., 6 (12) 1491, 2017.

54. DERESSA T.T., HASSAN R.M., RINGLER C., ALEMU T., YESUF M. Determinants of farmers' choice of adaptation methods to climate change in the Nile Basin of Ethiopia. Global environmental change, 19 (2), 248, 2009.

55. SINGH R.K., ZANDER K.K., KUMAR S. Perceptions of climate variability and livelihood adaptations relating to gender and wealth among the Adi community of the eastern Indian Himalayas. Appl Geogr 86, 41, 2017.

56. DRAFOR I., AGYEPONG K.A. Local information systems for community development in Ghana. Improving information flows to the rural community. 5, 2005.

57. BRUVOLD W., CROOK J. What the public thinks: reclaiming and reusing wastewater. Water Eng. Manage 128 (4), 65, 1981.

58. ASHRAF M., SAFDAR M.E., SHAHZAD S.M., AZIZ A., PIRACAHA M.A., SULEMAN M., AHMAD M.B. Challenges and opportunities for using wastewater in agriculture: a review, Journal of Applied Agriculture and Biotechnology, 2 (2), 1, 2017.

59. TARIQ S.R., SHAH M.H., SHAHEEN N., KHALIQUE A., MANZOOR S., JAFFAR M. Multivariate analysis of trace metal levels in tannery effluents in relation to soil and water: A case study from Peshawar, Pakistan. Journal of environmental management, 79 (1), 20, 2006.

60. CARR G., POTTER R.B., NORTCLIFF, S. Water reuse for irrigation in Jordan: Perceptions of water quality among farmers. Agricultural Water Management, 98 (5), 847, 2011.

61. MOLINOS-SENANTE M., HERNÁNDEZ-SANCHO F., SALA-GARRIDO R. Costebenefit analysis of waterreuse projects for environmental purposes: A case study for Spanish wastewater treatment plants, Journal of Environmental Management 92, 3091, 2011.

62. TRINH L.T., DUONG C.C., STEEN P.V.D., LENS P.N.L. Exploring the potential for wastewater reuse in agriculture as a climate change adaptation measure for Can Tho City, Vietnam, Agricultural Water Management 128, 43, 2013.

63. ULLAH Z., KHAN H., WASEEM A., MAHMOOD Q., FAROOQ U. Water quality assessment of the River Kabul at Peshawar, Pakistan: industrial and urban wastewater impacts. Journal of Water Chemistry and Technology, 35, 170, 2013.

64. RAJA S., CHEEMA H.M.N., BABAR S., KHAN A.A., MURTAZA G., ASLAM U. Socio-economic background of wastewater irrigation and bioaccumulation of heavy 
metals in crops and vegetables. Agriculture Water Management, 158, 26-34, 2015.

65. PATT A.G., SCHRÖTER D. Perceptions of climate risk in Mozambique: implications for the success of adaptation strategies. Global Environmental Change, 18 (3), 458, 2008.

66. MAHEEN H., HOBAN E. Rural women's experience of living and giving birth in relief camps in Pakistan. PLoS currents, 9, 2017.

67. HOANH C.T., TUONG T.P., JOHN W.G. Environment and Livelihoods in Tropical Coastal Zones: Managing Agriculture-fishery- Quaculture Conflicts, the UK by Biddles. SH134.6.E58 2006639.80913-dc22, Norfolk, 2006.

68. NDMA, 2014. Pakistan Floods 2014: Recovery Needs Assessment and Action Framework 2014-16. NDMA. Available at:. National Disaster Management Authority, Islamabad Accessed 21 November 2015. http://www.ndma. gov.pk/BooksPublications.php_2014.

69. HARVEY D. Seventeen contradictions and the end of capitalism. Oxford University Press, USA. 2014.

70. GORST C., KWOK C.S., ASLAM S., BUCHAN I., KONTOPANTELIS E., MYINT P.K., .MAMAS M. A. Long-term glycemic variability and risk of adverse outcomes: a systematic review and meta-analysis. Diabetes Care, 38 (12), 2354, 2015.

71. JAMSHIDI O., ASADI A., KALANTARI K., AZADI H., SCHEFFRAN J. Vulnerability to climate change of smallholder farmers in the Hamadan province, Iran. Climate Risk Management, 23, 146, 2019.

72. SHUKLA R., AGARWAL A., SACHDEVA K., KURTHS J., JOSHI P.K. Climate change perception: an analysis of climate change and risk perceptions among farmer types of Indian Western Himalayas. Climatic Change, 152 (1), 103, 2019.

73. HAY J., MAMURA N. The changing nature of extreme weather and climate events: risks to sustainable development. Geomat. Nat. Hazards Risk 1 (1), 3, 2010.

74. TINGJU Z., XIE H., WAQAS A., RINGLER C., IQBAL M.M., GOHEER M.A., SULSER T. Climate Change and Extreme Events, Impacts on Pakistan's Agriculture. International Food Policy Research Institute (IFPRI) (PSSP Policy Note 002). 2014.

75. FAHAD S., WANG J., HU G.Y., WANG H., YANG X.Y., SHAH A.A., HUONG N.T.L., BILAL A. Empirical analysis of factors influencing farmers crop insurance decisions in Pakistan: evidence from Khyber Pakhtunkhwa province. Land Use Policy 75, 459, $2018 \mathbf{b}$.

76. AKTAR M.W., PARAMASIVAM M., GANGULY M., PURKAIT S., SENGUPTA D. Assessment and occurrence of various heavy metals in surface water of Ganga river around Kolkata: a study for toxicity and ecological impact. Environmental monitoring and assessment, 160 (1), 207, 2010.
77. RIM-RUKEH A., IKHIFA O.G., OKOKOYO A.P. Effects of agricultural activities on the water quality of Orogodo River, Agbor Nigeria. J Journal of applied sciences research, 2 (5), 256, 2006.

78. YOUNAS U., IQBAL S., SALEEM A., IQBAL M., NAZIR A., NOUREEN S., MEHMOOD K., NISAR N. Fertilizer industrial effluents: Physico-chemical characterization and water quality parameters evaluation. Acta Ecologica Sinica 37, 236, 2017.

79. PATIL P.N., SAWANT D.V., DESHMUKH R. Physicochemical parameters for testing of water - a review. International Journal of Environmental Sciences, 3, 1194, 2012.

80. MAHANANDA M., MOHANTY B., BEHERA N. Physico-chemical analysis of surface and ground water of Bargarh District, Orissa, India. Int J Res Rev Appl Sci 2, 284, 2010.

81. FARAG A.M., MAY T., MARTY G.D., EASTON M., HARPER D.D., LITTLE E.E., CLEVELAND L. The effect of chronic chromium exposure on the health of Chinook salmon (Oncorhynchus tshawytscha). Aquatic toxicology, 76, 246, 2006.

82. AL-MUSHARAFI S.K., MAHMOUD I.Y., AL-BAHRY S.N. Heavy Metal Pollution from Treated Sewage Effluent. APCBEE Procedia 5, 344, 2013.

83. BARBOSA B., COSTA J., FERNANDO A.L., PAPAZOGLOU E.G. Wastewater reuse for fiber crops cultivation as a strategy to mitigate desertification, Industrial Crops and Products 68, 17, 2015.

84. IQBAL S., INAM A., INAM A., ASHFAQUE F., SAHAY S. Potassium and wastewater interaction in the regulation of photosynthetic capacity, ascorbic acid and capsaicin in chilli (Capsicum annum L.) plant. Agricultural water management, 184, 201, 2017.

85. ASHRAF M., IMTIAZ M., ABID M., AFZAL M., SHAHZAD S.M. Reuse of wastewater for irrigating tomato plants (Lycopersicon esculentum L.) through silicon supplementation. Journal of Water Reuse and Desalination, 3, 128, 2013.

86. AZEEM H.A. Analysis of industrial waste water from Kot Lakhpat area (Lahore, Pakistan) by Atomic Absorption Spectrometer. Biologia (Poland), 55, 35, 2009.

87. KUMARI V., TRIPATHI A.K., KANNAN A. Evaluation of Heavy Metals Toxicity of Pharmaceuticals Industrial Wastewater by Pollution Indexing and Chemometric Approaches. International Journal of ChemTech Research 10 (5), 718, 2017.

88. HANIF M.A., NADEEM R., RASHID U., ZAFAR M.N. Assessing pollution levels in effluents of industries in city zone of Faisalabad, Pakistan. Journal of Applied Sciences 5 (10), 1713, 2005. 
